\title{
Optometry's role in the care of patients with Diabetes
}

\section{Le rôle de l'optométrie dans le traitement des patients diabétiques}

$\prod_{\mathrm{s}}^{\mathrm{h}}$

The diabetes committee was struck in October of 2006 in response to CAO Council's call to ready Canadian Optometry for a mega trend in health care; diabetes. Specifically, the terms of reference of the committee were to promote optometry's role in the care of patients with diabetes, maintain relations with the Canadian Diabetes Association (CDA) at a national level, assist provincial associations and individual members in activities with CDA and to promote and comment on government and stakeholder policy related to diabetes

I am very fortunate to have Dr. Michael Dennis of BC, Dr. Garry Best of NL, Dr. Marta Witer of ON, and Dr. Henry Smit as members on my committee. Together we have accomplished a great deal.

Our committee's first order of business was to review the structure of the CDA and to identify key personnel that we would need to communicate with. This was accomplished with the guidance of Dr. Dennis who serves on the CDA Board, BC Region. He introduced me to a wide range of $\mathrm{CDA}$ officials including the chairman of the CDA Expert Review Committee of the 2008 Clinical Practice Guidelines (CPG's) while I attended the Annual Meeting and Professional Conference of CDA in Vancouver in October 2007.
We perused the CDA website and were successful in adding the definition of optometrist in the CDA diabetes dictionary. We developed a resource page on the CAO members' portal and it is now up to view. We also asked each province to appoint a CDA liaison to coordinate initiatives with CDA locally and to upload their activities to the diabetes site. $\mathrm{CAO}$ members were also encouraged to join CDA, Clinical and Scientific Section (CS\&S).

Our committee was one of the $70+$ expert external reviewers of the 2008 CPG's. We recommended to CDA that the initial examination of the fundi of newly diagnosed persons with diabetes be performed by an optometrist or ophthalmologist and not by the primary care physician (PCP) as was the recommendation in the 2003 CPG's. You will note that the 2008 CPG's now have a form for the PCP to check off optometrist or ophthalmologist as having examined the eyes. We believe this is a positive step.

We nominated Dr. Chris Hudson, from the School of Optometry, University of Waterloo to serve on the Executive of the Clinical and Scientific Section of CDA. Although he was not named, we will pursue this again during the next nominating process. Thank you to Dr. Hudson for letting his name stand.

Our committee was asked by $\mathrm{CAO}$ to

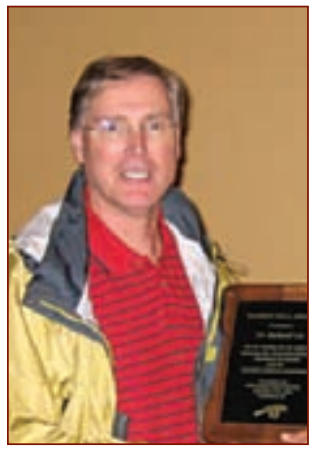

Dr Richard Lee, BSc, OD Chair, Diabetes Committee Canadian Association of Optometrists / Président, comité du diabète,

L'Association canadienne des optométristes. 
author a core document on optometry's role in the care of the person with diabetes. This was an arduous task that required a thorough review of the literature on all aspects of diabetes. We strove to present evidence based facts in a succinct, clinical format. We would especially like to acknowledge Dr. Hudson for sharing his expertise on the pathophysiology of the diabetic retina and for contributing substantially to the content of the text.

We advocated a CAO booth at the 2008 CDA Annual Meeting and Professional Conference in Montreal at which there are 2500 attendees comprised mostly of diabetic educator nurses and to a lesser extent dietitians, pharmacists, PCP's and endocrinologists. Topcon Canada supplied us with a state of the art digital retinal camera for which we were grateful. Our message at the conference was clear; optometrists do the vast majority of eye examinations in Canada, diabetes is the leading cause of blindness in the 25-75 age group, people with diabetes are 25 times more likely to be

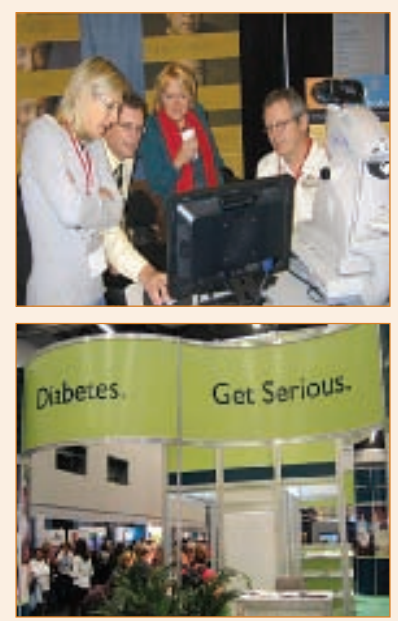

\section{Live Smart Diabetes Expos}

The Canadian Diabetes Association held Live Smart Diabetes Expos throughout Canada in 2008. The CDA promoted the Expos to the public as a way to "help prevent and manage diabetes while improving overall health at a daylong event that draws together diabetes-related products, resources, speakers and experts".

The CDA asked the Canadian Association of Optometrists to assist in recruiting optometrists to participate in the Expos as featured presenters or at 'Ask The Expert' sessions. In several communities, CAO helped coordinate delivery of a retinal camera which was used by volunteer optometrists to demonstrate the assessment of eye health.

CAO wishes to thank Mr. Al Brooks, TOPCON Canada Inc, who coordinated the use of a TOPCON TRC-NW6S Non-Mydriatic Retinal Camera System at several CDA Expos including Cornwall, Burlington, Sault Ste. Marie, Kingston, Edmonton, St. John's and Montreal. TOPCON has always been supportive in adding value to these community outreach events as well as assisting with CAO's public relations efforts during October Eye Health Month. TOPCON also donated a camera for use by CAO at the Professional Conference and Annual Meeting of the Clinical \& Scientific Section of the CDA.

The national Council of the CAO will hold its Fall 2008 meeting in conjunction with the CDA meetings. Several CAO Councillors and members of the CAO Diabetes Committee volunteered to attend sessions, network and participate at the CAO booth.

CAO thanks all optometrists who participated in the CDA Expos and at the annual conference/ AGM. It is difficult to confirm the names of volunteers given that in some communities, CDA recruited optometrists directly or it worked through provincial Optometry associations. We thank CDA for inviting 


\section{ÉDITORIAL INVITÉ GUEST EDITORIAL}

blind than people without diabetes and that digital photography is approved for screening for diabetic retinopathy but it is not intended to replace the need for people with diabetes to have periodic dilated eye examinations by optometrists or ophthalmologists. We also conveyed that optometrists check for glaucoma, cataracts and macular degeneration. The message was well received to the extent that several diabetic nurse educators from various provinces asked to have optometry provide a presentation on diabetic retinopathy and other eye care topics. I would like to thank Drs. Len Koltun, Denis Champagne, Henry Smit, Barry Thienes, Michael Dennis, and CAO staff Ms. Claudette
Gagnon for operating our booth.

The diabetes committee recommended that optometry be represented in the poster or oral presentation of abstracts segment of the professional conference. We would like to thank Dr. Langis Michaud of the University of Montreal, School of Optometry for submitting two articles to the abstract sub- optometrists to participate in its events/meetings and for its recognition of the important role the profession plays in the eye care of patients with diabetes.

\section{Expositions sur le diabète "Vivez pleinement »}

L'Association canadienne du diabète a tenu partout au Canada en 2008 des expositions d'une journée intitulées « Vivez pleinement ». Ces expositions «réunissaient des produits, des ressources, des conférenciers et des spécialistes qui indiquaient de quelle manière les Canadiens peuvent aider à prévenir et à gérer le diabète tout en améliorant l'état de leur santé en généra/».

L'ACD a demandé à I'Association canadienne des optométristes de l'aider à recruter des optométristes pour participer aux expositions à titre de présentateurs vedettes ou d'animateurs des séances "Demandez au spécialiste ». Dans plusieurs collectivités, I'ACO a aidé à obtenir un rétinographe que des optométristes bénévoles ont utilisé pour démontrer les résultats d'une évaluation de la santé oculovisuelle.

L'ACO remercie M. Al Brooks, TOPCON Canada
Inc, qui a prêté un rétinographe non mydriatique TOPCON TRC-NW6S à plusieurs expositions de l'ACD, notamment à Cornwall, à Burlington, à Sault Ste. Marie, à Edmonton, à St. John's et à Montréal. TOPCON a toujours contribué à de telles activités de rayonnement communautaire. De plus, TOPCON a fait don d'un rétinographe que I'ACO utilisera à la conférence professionnelle et à l'assemblée annuelle de la Section clinique et scientifique de I'Association canadienne du diabète. En outre, le Conseil national de l'ACO tiendra son assemblée de l'automne 2008 de concert avec les réunions de I'ACD. Plusieurs conseillers de I'ACO et membres du Comité du diabète de l'ACO ont accepté gracieusement d'assister à des séances, de faire du réseautage et de participer aux activités du kiosque de l'ACO.

L'ACO remercie tous les optométristes qui ont participé aux expositions de I'ACD et à la conférence annuelle/AGA. II est difficile de confirmer le nom des bénévoles puisque l'ACD, dans certaines collectivités, a recruté directement des optométristes ou a utilisé les services d'une association optométrique provinciale. Nous remercions I'ACD d'avoir invité les optométristes à participer à ses activités et assemblées et aussi d'avoir souligné l'important rôle que la profession joue dans les soins oculovisuels des patients atteints de diabète. 
mission committee. We would also like to congratulate Mylene Pouliot, Rejean Couture, and Elvire Vaucher of the School of Optometry and Department of Physiology of the University of Montreal for their fascinating poster on Modulation of Retinal Blood Flow in Type 1 Diabetic Rats by Kinins B Receptor.

Having acquired two years of experience with diabetes and the CDA I am now convinced that the diabetic nurse educators are the 'VIPs' of coordinating eye care for people with diabetes and that our committee must be directed to cultivating interaction with them. They are well trained and very knowledgeable in the area of diabetes care and we can learn a lot from each other. As our president, Dr. Koltun, states so aptly "Communication is the Key!"

In closing it has been my pleasure to work with committee members Mike, Marta, Garry and Henry. On behalf of the committee we thank $\mathrm{CAO}$ and all members for your continued support.

\section{I} e comité du diabète a été créé en octobre 2006 après que le déà l'optométrie canadienne de se tenir prête à faire face à un phénomène susceptible d'envahir les soins de santé, en l'occurrence le diabète.

Plus particulièrement, ce comité s'est donné pour mandat de promouvoir le rôle de l'optométrie dans le traitement des patients atteints de diabète, d'entretenir des relations avec l'Association canadienne du diabète à l'échelon national, d'aider les associations provinciales et les membres individuels dans diverses activités avec l'ACD, et enfin de promouvoir et de commenter la politique d'intervention des administrations publiques et des intervenants en ce qui concerne le diabète. Je suis très fortuné d'être entouré au comité du Dr Michael Dennis (C.-B.), du Dr Garry Best (N.-É.), de la Dre Marta Witer (Ont.) et du Dr Henry Smit (N.-É.). Nous avons accompli beaucoup de choses ensemble.

La première tâche à l'ordre du jour de notre comité consistait à examiner la structure de l'ACD et à identifier les personnes clés avec lesquelles nous communiquerions. Cette tâche a été menée à bien sous la direction du Dr Dennis, qui a siégé au Conseil de l'ACD pour la région de la C.-B. Il m'a fait connaitre un vaste éventail de représentants de l'ACD, notamment le président du comité d'experts, des lignes directrices de pratique clinique 2008 (LDPC), pendant que j'assistais à l'assemblée annuelle et à la conférence professionnelle de l'ACD à Vancouver en octobre 2007.

Après examen du site Web de l'ACD, nous avons pu faire ajouter la définition d'un optométriste dans le dictionnaire du diabète de l'ACD. Nous avons créé une page de ressources que les membres de l'ACO peuvent maintenant consulter sur leur portail. Nous avons aussi demandé à chaque province de nommer une personne-ressource auprès de l'ACD afin de coordonner les initiatives locales de l'ACD et faire connaitre ses activités sur le site de l'Association. Nous avons aussi incité les membres de l'ACO à adhérer à la Section clinique et scientifique de l'ACD.

Notre comité a été l'un des 70 spécialistes et plus de l'extérieur qui ont examiné les lignes directrices de pratique clinique 2008. Nous avons recommandé à l'ACD que le premier examen du fond de l'œil des patients nouvellement diagnostiqués diabétiques soit fait par un optométriste ou un ophtalmologiste et non par le médecin de soins primaires (MSP), comme le recommandaient les lignes directrices 2003. Vous remarquerez que les LDPC 2008 com portent dorénavant un formulaire sur lequel le médecin de soins primaires peut indiquer si l'examen des yeux a été fait par un optométriste ou un ophtalmologiste. Il s'agit là à notre avis d'une mesure positive.

Nous avons proposé la candidature du Dr Chris Hudson, École d'optométrie de l'Université de Waterloo, à l'exécutif de la Section clinique et scientifique de l'ACD Même si le Dr Hudson n'a pas été nommé, nous reviendrons à la charge lors du prochain processus de mise en candidature. Nous remercions le Dr Hudson de s'être porté volontaire à cette fin.

L'ACO a demandé à notre comité de rédiger un document de base sur le rôle de l'optométrie dans le traitement des personnes atteintes de diabète. Cette immense tâche nous a obligés à faire une recension complète des textes sur tous les aspects du diabète. Nous nous sommes efforcés de réunir des données factu- 


\section{ÉDITORIAL INVITÉ GUEST EDITORIAL}

elles sous une présentation clinique succincte. Nous remercions tout particulièrement le Dr Hudson de ses explications sur la pathophysiologie de la rétine diabétique et de sa vaste contribution au document.

Nous avons recommandé à l'ACO qu'elle tienne un kiosque à l'assemblée annuelle et à la conférence professionnelle de l'ACD 2008 à Montréal, qui réunit quelque 2500 personnes, principalement des infirmières éducatrices en diabète et, dans une moins large mesure, des diététistes, des pharmaciens, des médecins de soins primaires et des endocrinologues. Topcon Canada nous a fourni un rétinographe numérique dernier cri, geste que nous avons énormément apprécié. Notre message à la conférence était clair : les optométristes accomplissent la très grande majorité des examens de la vue au Canada, le diabète est la principale cause de cécité dans le groupe des 25-75 ans, les personnes diabétiques sont 25 fois plus susceptibles d'être aveugles que les personnes sans diabète, et enfin la photographie numérique est un moyen approuvé pour dépis- ter la rétinopathie diabétique, mais elle ne remplace par les examens de la vue avec pupilles dilatées que les optométristes ou ophtalmologistes doivent périodiquement dispenser aux personnes atteintes de diabète. Nous avons aussi indiqué que les optométristes devaient vérifier la présence de glaucome, de cataractes et de dégénérescence maculaire. Le message a été bien reçu dans la mesure où plusieurs infirmières éducatrices en diabète de diverses provinces ont demandé à l'optométrie de faire une présentation sur la rétinopathie diabétique et sur les autres soins oculovisuels. Je remercie les Drs Len Koltun, Denis Champagne, Henry Smit, Barry Thienes et Michael Dennis de même que le personnel de l'ACO (Mme Claudette Gagnon) du temps qu'ils ont passé dans le kiosque.

Le comité du diabète a recommandé que l'optométrie soit représentée sur l'affiche ou dans la présentation orale des résumés à la conférence des professionnels. Nous remercions le Dr Langis Michaud, École d'optométrie de l'Université de Montréal (UM), des deux articles qu'il a présentés au comité des résumés. Nous félicitons aussi Mylène Pouliot, Réjean Couture et Elvire Vaucher, École d'optométrie et Département de physiologie de $\mathrm{UM}$, de leur affiche fascinante sur la modulation du flux sanguin rétinien chez des rats diabétiques de type 1 par le récepteur de la kinine B.

Ayant acquis deux années d'expérience du diabète et des activités de l'ACD, je suis convaincu que les infirmières éducatrices en diabète sont les principales coordonnatrices des soins oculovisuels pour les personnes atteintes de diabète, et que notre comité devrait être tenu de travailler avec elles. Elles ont une formation et des connaissances supérieures dans le traitement du diabète et nous pouvons grandement bénéficier d'un échange mutuel. Comme l'a si bien dit notre président, le Dr Koltun, « la communication est la clé! ».

En terminant, j'ai eu beaucoup de plaisir à travailler avec les membres du comité, à savoir Mike, Marta, Garry et Henry. Au nom du comité, nous remercions l'ACO et tous les membres de leur appui continuel. $\%$
CNIB CONSUMER PRODUCTS: MAKING LIFE EASIER

The CNIB Consumer Products Catalogue features hundreds of products designed to improve life for people with vision loss. The large print catalogue is available in French or English and features everything from talking watches to large print crosswords. It is a handy resource for your patients, family or friends.

Get a free copy to display in your waiting room: (866) 659-1843 or online www.webstore.cnib.ca

\section{ASSOCIATE WANTED}

Associate optometrist wanted to join our dynamic, wellestablished practice located in Victoria, British Columbia. Our office is situated in a suburban setting close to UVic.

We are well known in Victoria and the surrounding area for our outstanding professional care and service. A great team of fun, well-trained assistants makes our patients happy and the office run smoothly. Our present associate Doctors are enjoying personal gross incomes of over $\$ 200,000$ per year.

Please contact us if you are interested in joining our team; Arnie Eitutis(UW80) 250-477-5636 oremail to eitutis@shaw.ca . 